\title{
Pastorale begeleiding van kinders wat rou
}

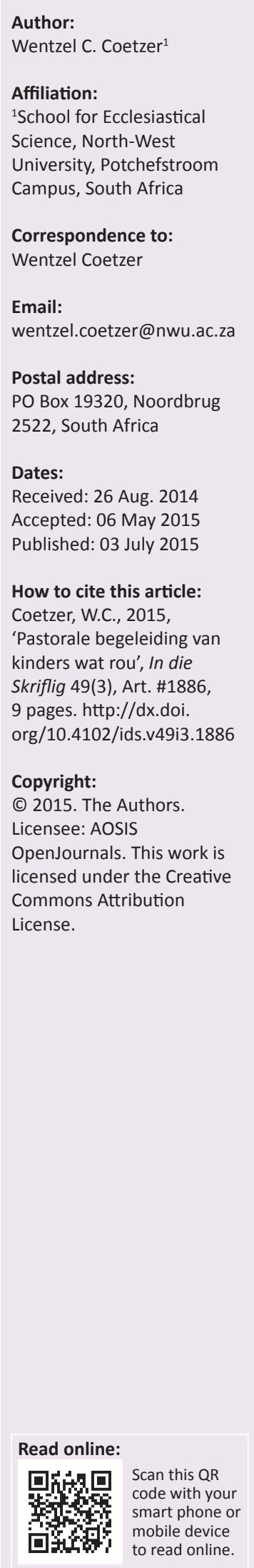

In die literatuur word dikwels na kinders as die sogenaamde 'forgotten grievers' verwys. Wat pastorale berading betref is daar in die verlede tydens sterfgevalle in 'n gesin soms meer op die volwassenes as op die kinders gefokus. Verliese wat egter nie tydens die kinderjare verwerk word nie, het 'n impak op die res van so 'n persoon se lewe. In hierdie artikel word die belangrikheid van kinders as volle lede van die geloofsgemeenskap (ook wat hulle emosies betref) beklemtoon. Aspekte soos die sinvraag, die beskermende- en helende effek van spiritualiteit en geloof, asook die belangrikheid van 'n Skrifgedeelte soos Lukas 18:15-17 met betrekking tot kleiner kinders kom vervolgens aan die orde. Die belangrikheid van die integrering van spiritualiteit en kreatiewe, ekspressiewe tegnieke en strategieë word ook uitgelig. Voorbeelde van laasgenoemde tegnieke word vervolgens aan die orde gestel terwyl 'n aantal praktiese riglyne ten opsigte van geloofsaspekte ter begeleiding van die kind wat 'n verlies ervaar het, ook daarna aandag geniet.

Pastoral care of grieving children. Literature often refers to children as the so called forgotten grievers. In the past, during deaths in a family, pastoral counselling was sometimes more focused on the adults than on children. However, losses that are not processed during childhood will have an impact on the rest of such a person's life. In this article, the importance of children as full members of the community of faith (also regarding their emotions) is emphasised. Aspects such as the question on meaning, the protective and healing effect of spirituality and faith, and the importance of a passage like Luke 18:15-17 with respect to smaller children are discussed. The importance of the integration of spirituality and creative expressive techniques and strategies are also explored. Examples of the latter techniques are discussed, while a number of practical guidelines on religious issues for the guidance of the child who has experienced a loss also receive attention.

\section{Inleidend}

In die verlede het dit dikwels gebeur dat die pastorale begeleiding ten tyde van ' $n$ sterfgeval in 'n gesin hoofsaaklik op die volwassenes gefokus was. In hierdie verband word daar in die literatuur na die kind as die 'forgotten griever or mourner' verwys (Crehan 2004:203; Dyregrov 2008:9; Horsley \& Patterson 2006:131).

Volgens navorsing oor die rouproses by kinders, was daar byvoorbeeld voor 1960 'n sterk denkstroom wat die standpunt gehuldig het dat kinders nie werklik in staat is om emosies van rou (grief) te ervaar nie. Hierdie denkstroom was grootliks die resultaat van die standpunt van die psigiater Freud (vgl. Erwin 2002:466) wat gesuggereer het dat kinders nie in staat is om te rou totdat hulle oor die vermoë beskik om die realiteit te toets (reality testing) ${ }^{1}$ en objek-konstantheid (object constancy) ${ }^{2}$ te ervaar nie (vgl. Zonnebelt-Smeenge \& De Vries 2013).

Sedert die sestigerjare van die vorige eeu het die psigiater John Bowlby se sogenaamde 'attachment theory' egter 'n groot impak begin maak (vgl. Bretherton 1992; Cassidy \& Shaver 1999:3). Hierdie teorie het die noue band tussen kinders en hulle sorgdraers sterk beklemtoon en navorsing in hierdie verband het al hoe meer die teendeel bewys ten opsigte van vroeëre standpunte rondom die rouproses by kinders. 'n Uitgangspunt soos die volgende het byvoorbeeld al hoe sterker in die literatuur na vore gekom: 'Anyone old enough to love is old enough to mourn' (Hope \& Hodge 2006:108; O'Connor 2004:105). Daar is gevolglik al hoe meer erkenning aan die talle verliese verleen wat kinders gedurende hulle kinderjare ervaar en ook die impak wat dit op die res van

\footnotetext{
Daar is'n onderskeid tussen die interne wêreld van gedagtes en gevoelens en die eksterne wêreld (bv. kinders wat hulle oë toehou en dan dink omdat húlle nie kan sien nie, mense hulle ook nie kan sien nie). Die vermoë tot realiteitstoetsing behels die vermoë om tussen dan dink omdat húlle nie kan sien nie, mense hulle ook nie kan sien nie). Die vermoë tot realiteitstoetsing behels die vermoë om tussen
jouself en die wêreld rondom jou te onderskei, en ook die besef dat jy positief of negatief deur invloede en perspektiewe rondom jou beïnvloed kan word.
}

2.Wanneer 'n objek uit sig verdwyn, impliseer dit nie noodwendig dat die objek ophou om te bestaan nie. 
hulle lewe kan hê indien hierdie verliese nie verwerk word nie. Daarom is dit, volgens Zonnebelt-Smeenge en De Vries (2013), so belangrik dat hulle gesonde wyses sal aanleer om die dood en hartseer te hanteer. Indien dit nie gebeur nie, het dit gewoonlik negatiewe langtermyngevolge soos onder meer deur Wright (2011) verwoord word:

Time after time I have seen the ungrieved losses of childhood interfere with an adult's ability to respond to life and relationships. And this, in time, can turn an adult loss into a crisis. (p. 331; vgl. ook Kaufman \& Kaufman 2005:237)

Binne dieselfde konteks kan ook na die uitspraak deur Elizabeth Kübler-Ross (1997:66) in haar beskrywing van die oorsaak van onverwerkte rousmart by talle volwassenes verwys word: '... [N]ever having resolved the hurts of childhood'.

Wat die situasie in Suid-Afrika betref, berig United Nations International Children's Emergency Fund (UNICEF 2014) dat daar tans ongeveer 3.7 miljoen weeskinders is. Ongeveer die helfte van hierdie getal het hulle ouers as gevolg van MIV en vigs-verwante siektes verloor. In hierdie verslag word verder na ongeveer 150000 kinders verwys wat in huishoudings woon waar kinders self aan die hoof is. Dit is uiteraard ' $n$ terrein met unieke uitdagings en besondere problematiek, wat nie binne die parameters van hierdie artikel hanteer kan word nie. ${ }^{3}$

\section{Fokus sowel as basiese vertrekpunte}

Die navorsingsvraag van hierdie artikel is die volgende: In watter mate kan die pastoraat ${ }^{4}$ voortaan vir die 'geestelike verwaarlosing' van die verlede kompenseer van kinders wat deur 'n rouproses gaan (forgotten mourners)? Die uitdaging van hierdie vraag sluit in 'n mate by Botha (2010:41) se definiëring van Praktiese Teologie aan, naamlik as onder andere die verbetering en vernuwing van die oue en die ontdekking van die nuwe. Wat metodologie betref val die klem op 'n literatuurstudie met kritiese opmerkings. Daar word eerstens op die verskillende ontwikkelingsfases van kinders gefokus. Daarna verskuif die fokus na die sinvraag asook ander geestelike vrae. Die beskermende en helende effek van spiritualiteit en geloof kom vervolgens aan die orde. Daarna word op die belangrike implikasies ten opsigte

\footnotetext{
3.Die boek, The child within, deur Rankin en Cochrane (2008) bied in hierdie verband 'n baie praktiese toerustingsprogram vanuit 'n Christelike basis vir gemeenskapswerkers wat 'n passie het om by weeskinders (as gevolg van gemeenskapswerkers wat ' $n$ passie het om by weeskinders (as gevolg van
MIV en vigs) betrokke te raak. Rankin is ' $n$ sielkundige wat in werkwinkels met MIV en vigs) betrokke te raak. Rankin is ' $n$ sielkundige wat in werkwinkels met
getraumatiseerde kinders spesialiseer, terwyl Cochrane ' $n$ pastoor is. Die vermelde boek is deel van ' $n$ reeks hulpbronne wat deur Strategies for Hope uitgegee word en gratis by www.stratshope.org afgelaai kan word. Vergelyk in hierdie verband ook die artikel van Demmer en Rothschild (2011) wat ' $n$ oorsig van 'n gesamentlike navorsingsprojek deur die Universiteit van KwaZulu-Natal en die Lehman College in New York bied ten opsigte van die rol van verlies onder ' $n$ aantal swart adolessente as gevolg van MIV en vigs in KwaZulu-Natal.

4.Ter omskrywing van die breër taak van die pastoraat gee Swinton en Mowat (2006) die volgende beskrywing: Practical theology is critical, theological reflection on the practices of the Church as they interact with the practices of the world, with a view to ensuring and enabling faithful participation in God's redemptive practices in, to and for the world (p. 6). Daniël Louw (2012) fokus nog meer in op die uiteindelike oogmerke van hierdie artikel wanneer hy pastorale sorg soos volg definieer: To articulate life issues through language, symbols and metaphors so that the To articulate life issues through language, symbols and metaphors so that the
narratives of life can become linked to the narratives of scripture in such a way that narratives of life can become linked to the narratives of scripture in such
people discover identity and human dignity (spiritual humanism) (p. 15).
}

van die begeleiding van kinders vanuit 'n Skrifgedeelte soos Lukas 18:15-17 gelet. Laastens word op 'n aantal praktiese riglyne ten opsigte van geloofsaspekte gefokus.

Aangesien die term spiritualiteit telkens binne hierdie artikel figureer, is dit nodig om teen die agtergrond van die wye akademiese debat ${ }^{5}$ rondom hierdie aspek, die basiese vertrekpunt van hierdie artikel te verwoord. Saam met Louw (2012:194) word 'n keuse gemaak ten gunste van 'n geïntegreerde Christelike spiritualiteit waar die benadering aan 'praxis thinking' gekoppel is. Binne sodanige benadering word praktykgerigte denke aan die begrip ethos gekoppel, wat 'n baie spesifieke lewenswyse impliseer. Louw (2012:195) lys in hierdie verband 'n verskeidenheid aspekte soos onder andere vergifnis, versoening, verantwoordelike gedrag, die beginsel van geloof soos in die belydenisse van die kerk en die geloof vervat is en verder ook gepaste kommunikasie van die evangelie (wat ook pastorale berading kan insluit en die basiese voorbereiding van persone vir die lewe).

\section{Die verskillende ontwikkelingsfases van die kind}

Kinders se begrip ten opsigte van die dood hou verband met die ontwikkelingsfase waarbinne die spesifieke kind verkeer. In hierdie verband is dit krities belangrik dat beraders op hoogte sal wees van die verskillende ontwikkelingsfases by kinders ten einde 'n positiewe impak op hulle aanpassing by 'n geliefde se dood te kan maak (Muselman \& Wiggins 2012:229). Konsepte rondom geloof, godsdiens en God is uiters belangrik aangesien kinders se geloof, namate hulle ouer word en daar by hulle al hoe meer 'n soeke na die sin en betekenis van dinge is, aan hulle óf 'n geborgenheid, óf 'n onsekerheid sal bied. In hierdie verband is dit belangrik om die volgende fases te onderskei (vgl. Louw 1998:16; O'Connor 2004:21-25; Wright 2011:369-371; Zonnebelt-Smeenge \& De Vries 2013).

\section{0-2 jaar}

Tydens hierdie fase bestaan daar nog geen konsep oor die dood nie en die baba of kind sal op die ouers of versorgers se hartseer reageer. Indien 'n ouer tydens hierdie fase van die kind se lewe sou sterf, word die verlies van die bindingsverhouding (Bowlby se attachment theory aangehaal in Bretherton 1992) deur die kind ervaar. Aangesien babas en klein kindertjies ook nie 'n konsep van tyd het nie, word die dood as 'n leegte of afwesigheid ervaar van iemand wat vantevore ná aan die kind was.

\footnotetext{
5.Vergelyk in hierdie verband Ballard and Pritchard (2006:177-190), Houtman and Aupers (2007:305), Reader (2008:61-72), Tanyi (2002:500-509). Koenig (2008) beskryf hierdie debat soos volg: Spirituality is increasingly being examined as a construct related to mental and physical health. The definition of spirituality, however, has been changing. Traditionally, spirituality was used to describe the deeply religious person, but it has now expanded to include the superficially religious person, the religious seeker, the seeker of well-being and happiness, and religious person, the religious seeker, the seeker of well-being and happiness, and
the completely secular person (p. 349).

lemand soos Stifoss-Hanssen (1999) reflekteer weer die ander standpunt: I don't find the arguments convincing for giving sacredness such a central place in the definition of spirituality (existentiality would probably serve this goal better); and therefore spirituality is best seen as a wider concept than religion (p. 25). Vergelyk in hierdie verband ook die boek, Selling spirituality, deur Carette en King (2005).
} 


\section{2-3 jaar}

Tydens hierdie fase is die kind geneig om dood en slaap te verwar.

\section{3-5 jaar}

Kinders in hierdie fase het oor die algemeen begrip vir die feit dat wanneer iemand dood is, die persoon se liggaam ophou met werk. Die dood word soms ook as 'n tipe slaap gesien. Hier is ook nog iets van 'n magiese denke aanwesig in die sin dat die dood tydelik is en weer omgekeer sou kan word. Hierdie denke word versterk deur baie blootstelling aan strokiesprentkarakters (cartoons) wat telkens weer terugkom nadat hulle dood was. Daar mag gevolglik voortdurend vrae gevra word oor wanneer Pappa of Mamma weer gaan terugkom, of wanneer die troeteldier weer gaan wakker word.

Wat Oupa en Ouma se dood betref mag voorskoolse kinders selfs die indruk skep dat dit hulle nie so intens raak nie en dit mag by ouers vrae laat ontstaan of die kind 'op die regte wyse' rou. Vanuit 'n ontwikkelingsperspektief verstaan hierdie kind egter nog nie dat die dood permanent is nie.

Kinders binne hierdie ouderdomsgroep mag ook baie maklik foutiewelik oortuig wees dat hulle self moontlik die oorsaak van die geliefde se dood is. Ouers en beraders moet op gedrag let wat moontlik hiermee verband mag hou.

\section{5-9 jaar}

Gedurende hierdie fase begin die kind gewoonlik verstaan dat die dood permanent is. Die dood word egter steeds as 'n onpersoonlike krag beskou en die kind vind dit nog moeilik om te begryp dat dit êrens met alle mense gebeur en dus ook met hulself kan gebeur. Hulle begin gewoonlik al hoe meer konkrete vrae vra terwyl rituele vir hulle baie belangrik word. Wanneer 'n troeteldier gesterf het, sal dit byvoorbeeld vir hulle belangrik wees dat daar 'n begrafnisritueel plaasvind met gebede en so meer. As gevolg van dood in die gesin sou hulle op hierdie ouderdom heelwat probleme by die skool kon ontwikkel en ook moontlik met emosies soos woedeuitbarstings worstel.

\section{9-12 jaar (Pre-adolessensie)}

Tydens hierdie fase begin die kind volle begrip verkry vir die feit dat die dood onvermydelik, universeel en 'n biologiese feit is - elke lewende wese moet uiteindelik sterf. Hulle begin al hoe meer oor abstrakte konsepte besin soos die ewigheid, spiritualiteit, hemel en hel. Hulle is ook geneig om ander se reaksies fyn dop te hou met betrekking tot die dood en tot geliefdes wat nie meer daar is nie.

As daar in hierdie artikel na die begrip kind of kinders verwys word, word daar by 'n ouderdomskategorie van nie ouer as ongeveer 12 jaar nie volstaan (vgl. Louw 1998:16; O'Connor 2004:21-25; Wright 2011:369-371; Zonnebelt-Smeenge \& De Vries 2013).

\section{Trauma en verlies aktiveer gewoonlik die sinvraag asook ander geestelike vrae}

Trauma en verlies mag ' $n$ kind se sin vir identiteit en algemene perspektief ontwrig en die sinvraag asook ander geestelike vrae aktiveer. In hierdie verband wys Boynton en Vis (2011:138) op die feit dat terapeutiese strategieë ten opsigte van traumatiese rou en verlies by kinders in die verlede hoofsaaklik op die bevordering van aspekte soos gesonde aanpassing, uithouvermoë (resilience) en oorlewing (coping), psigopatologie (angs, depressie, post-traumatiese stresversteuring), psigo-opvoeding en kognitiewe herstrukturering gefokus was. Binne hierdie literatuur was daar egter oor die algemeen 'n afwesigheid van terapieë waarby sowel spiritualiteit as kreatiwiteit ingesluit is.

Wat spiritualiteit betref, wys navorsing volgens Batten en Oltjenbruns (1999:530) op die betekenisvolle verskil in die lewe van kinders wat God as die deurslaggewende faktor ontdek het. Hierdie blyk 'n betekenisvolle en herhalende tema in hulle proses van geestelike groei te wees asook die vind van hernude lewensin na die verlies van 'n gesinslid.

Wat die aspek van kreatiwiteit betref, pleit Boynton en Vis (2011) vir 'n holistiese raamwerk van beradingsintervensies:

Since children seek meaning through play, stories, and dialogue these activities are important strategies in spiritually sensitive counselling practices. Creative expressive therapies involving play, stories and dialogue offer spiritual pathways to meaning making that allow for transformation and healing from traumatic grief and/or loss. (p. 139)

Wanneer tradisionele praatterapieë nie meer effektief is nie, blyk kreatiewe ekspressiewe tegnieke en strategieë meer effektief te wees. In hierdie verband wys Boynton en Vis (2011:147) op kalmerende aktiwiteite soos strelende musiek, vredevolle beelde of prente, skryf, teken, storievertel, herdenking (commemorating) en ritualisering wat posttraumatiese groei kan fasiliteer asook kunsterapie, musiek, spel en storievertelling wat weer kreatiewe uitdrukking en emosionele prosessering van geestelike vrae en kwessies kan fasiliteer. ${ }^{6}$ Onder die paragraaf wat oor die gebruikmaking van kreatiewe- en ekspressiewe elemente handel, sal in meer detail op laasgenoemde aspekte gefokus word.

Teen bovermelde agtergrond wys Muselman en Wiggins (2012:234) op die feit dat verskeie navorsers gedurende die laaste twee dekades 'n sterk saak vir die integrasie van godsdiens of spiritualiteit '... into mental health practice' uitgemaak het (vgl. in hierdie verband ook Frame 2003; Gold 2010; Kelly 1995; Richards \& Bergin 2000).

6.Van der Kolk en Fisler (1995:505-525) wys daarop dat traumatiese geheue nie noodwendig in velo format cencol sensoriese formate. Verbale tegnieke gaan daarom in sekere gevalle baie minder effektief wees om met herinnerings en pynlike emosies te werk en resultate te verkry. Dit mag dan nodig wees om met nie-verbale tegnieke te werk soos die beoefening van ' $n$ kunssoort soos skilder, teken of spelterapie, en beweging soos dans. 
Dit is ook baie algemeen dat kinders wat rou, net soos talle volwassenes, met die eeue oue vraag, 'Waarom (het dit gebeur)?', sal reageer nadat hulle emosioneel deur 'n groot verlies geraak is. In reaksie op hierdie vraag is dit belangrik om in gedagte te hou dat dit heel dikwels eerder om 'n emosionele noodkreet as ' $\mathrm{n}$ intellektuele vraag gaan (James, Friedman \& Matthews 2002):

Their primary reaction will be to the painful feelings they are experiencing. Your job is to acknowledge and assist them in recognizing, accepting, and dealing with the truth of those feelings. (p. 100)

\section{Die beskermende en helende effek van spiritualiteit en geloof}

Verskeie studies bevestig kinders se natuurlike geneigdheid om godsdienstige en geestelike betrokkenheid in hulle lewe te soek (Forliti \& Benson 1986; Jerome 2011; Miller 2009). Dit is belangrik om tydens krisisse kinders se sterkpunte te identifiseer en dan hulle spiritualiteit te gebruik om hulle vermoë tot insig te versterk asook om geloofstandpunte te bevestig wat hoop en optimisme promoveer.

Traumatiese gebeure daag kinders se ontwikkelende persepsies en veronderstellings aangaande die wêreld rondom hulle uit en tragedies wat dood insluit, lei onwillekeurig tot 'n ondersoek van die eie geloofsisteem. Tydens en ná krisisse is skoolgaande kinders geneig om op hulle geestelike geloofsbasis terug te val, ten einde sin van persoonlike- en kollektiewe lyding en verlies te maak, aangesien geloofstandpunte 'n verklaring vir ons menswees bied en ook sin en betekenis aan ons lewe gee (Jerome 2011:198).

Spiritualiteit word ook met 'n individu se basiese vertrekpunte (core values) geassosieer en dit dien gewoonlik as die dryfkrag vir die meeste van die menslike gedrag oor die algemeen (Louw 2012:194; vgl. ook Cochran, Wood \& Arneklev 1994:95). Daar is heelwat navorsing wat die verband tussen veerkragtigheid (resilience) en aanpasbare oorlewing (adaptive coping) bevestig enersyds, en andersyds op 'n effektiewe godsdienstige en geestelike geloof dui (Koenig, Kvale \& Ferrel 1988; Mattlin, Wethington \& Kessler 1990; Pargament et al. 1990; Pond 2012).

Jerome (2011) verwoord hierdie aspek treffend soos volg:

[S]piritual-mindedness assists children in increasing hope and optimism, accepting their situation with the support of others, and finding meaning despite seemingly unchangeable and incomprehensible circumstances. (p. 198)

\section{Enkele belangrike skriftuurlike merkers}

Rondom die aspek van die spirituele word vervolgens op 'n aantal insiggewende skriftuurlike perspektiewe gefokus wat vanuit 'n MA-verhandeling deur Jeanien Marx (2007) met die titel, Pastorale berading aan kinders met rousmart, na vore gekom het en wat ook op die tema van hierdie artikel van toepassing is. ${ }^{7}$

Jong kinders word nie in die Bybel spesifiek ten opsigte van rousmart uitgesonder nie en gevolglik is daar geen pertinente bybelse voorskrifte nie. Vanuit die Ou Testament is daar talle verwysings na weeskinders en weduwees na wie omgesien moet word. Uit verskeie gedeeltes in die Nuwe Testament blyk dit dat Jesus besonder besorg oor kinders was en dat Hy hulle by geleentheid ook geseën het. In die verhandeling van Marx (2007:16-28) val die fokus veral op die gedeelte in Lukas 18:15-17. ${ }^{8}$ Die kern van die betrokke perikoop word as Jesus se persoonlike bemoeienis met kinders beskryf, met die implikasie dat volwassenes hulle nie moet wegkeer nie. Met betrekking tot die tema van die rouproses by kinders is die implikasie belangrik dat Jesus Christus die uitsluiting van kinders sterk afkeur.

Jesus roep hulle nader, nooi hulle uit om tyd met Hom te spandeer en met Hom te praat en lê hulle dan die hande op en seën hulle (Lester 1995:39).

Volgens Marx (2007:28) wys die uitkoms van die studie van die perikoop duidelik op die volgende aspekte:

Kinders moet ingesluit en liefdevol ondersteun word in die tyd wat op die dood van familie of vriende, asook ander krisisse volg.

Wanneer ouers in 'n verhouding met Jesus die Groot Geneesheer staan, bring hulle die kinders in gesprek en gebed na Hom en kan hulle met reg op seën en genesing van emosionele pyn staatmaak.

Soos in die kernvers (Luk 18:16) benadruk word, is dit juis wanneer ignorering, onbetrokkenheid en uitsluiting nie plaasvind nie, dat die natuurlike verloop van rousmart by kinders moontlik is.

Met betrekking tot die tema van die rouproses by kinders is die implikasie belangrik dat Jesus Christus die uitsluiting van kinders sterk afkeur. Vrae van kinders oor die dood moet eerlik en eenvoudig beantwoord word en rituele rondom die afsterwe van mense wat aan die kind bekend is, moet verduidelik word.

\section{'n Aantal praktiese riglyne ten opsigte van geloofsaspekte}

Vervolgens word op 'n aantal praktiese riglyne vir die pastorale berader gefokus ter begeleiding van kinders wat hulself te midde van 'n rouproses bevind.

7.Vergelyk in hierdie verband ook die proefskrif van Linda Grobler (2013), Speel as hulpmiddel in die pastorale versorgingsproses van die getraumatiseerde laerskoolkind as gevolg van die dood van'n ouer.

8.In haar artikel, Childhood grief and the church's response, wys Pond (2012:48) ook op die belangrike teologiese betekenis van Matteus 18:1-6, 10 met betrekking tot klein in berijos kiners). Anders as talle a bever kinders). Anders as talle ander geloofsisteme van daardie tyd, gee die Christendom erkenning en aanmoediging ten opsigte van volle gesinsdeelname asook genade ongeag wat die persoon het om in ruil daarvoor aan te bied. 


\section{Gebruikmaking van kreatiewe- en ekspressiewe elemente}

Onder die paragraaf, 'Trauma en verlies aktiveer gewoonlik die sinvraag, asook ander geestelike vrae', is reeds op die feit gewys dat wanneer tradisionele praatterapieë nie meer effektief is nie, kreatiewe ekspressiewe tegnieke en strategieë meer effektief blyk te wees. Vervolgens word op 'n aantal voorbeelde in hierdie verband gefokus waarvan biblioterapie die eerste is.

\section{Biblioterapie}

Muselman en Wiggins (2012:236) wys in hierdie verband op die sinvolle gebruikmaking van ouderdomgebaseerde boeke wat verband hou met die wil van God, ten einde sin uit die negatiewe lewensgebeure te maak, met die toepassing van die Christelike geloof te midde van dood en rou.

\section{Skrifgedeeltes}

'n Dogter wat haar moeder verloor het, is gehelp om Skrifgedeeltes te soek wat verteenwoordigend was van haar geloof in God voor haar ma se dood; daarná Skrifgedeeltes wat op die woede dui wat sy teenoor God gehad het vir die dood; en dan gedeeltes wat op toekomstige moontlikhede van betekenis en hoop mag dui wat uit die tragedie sou kon voorspruit. Die bespreking van hierdie Skrifgedeeltes het haar gehelp om meer volledig uitdrukking aan al haar emosies, vrese en vrae te kon gee (Muselman \& Wiggins 2012:236).

\section{Geestelike joernaal}

Dit gaan hier om 'n terapeutiese oefening wat impliseer dat persone 'n geskrewe dagboek moes hou van hulle gevoelens, gedagtes, vrae, transendente ervarings asook refleksies ten opsigte van die betekenis, die doel en plek van God in hul lewe. Vir talle kinders help skryf om die angs dat hulle die persoon moontlik sal vergeet, te laat afplat. Verder dien dit ook as 'n effektiewe oefening om gevoelens te eksploreer en betekenis te skep. Cora is byvoorbeeld gevra om 'n brief aan God te skryf om daardeur uitdrukking aan haar frustrasies te gee en om ook alle moeilike vrae aan Hom te vra - in die proses het dit haar gehelp om haar vrae te artikuleer en geduld te beoefen om met daardie onbeantwoorde vrae te worstel (Muselman \& Wiggins 2012:237).

Perschy (2004:119) stel die volgende besprekingspunte en praktiese stappe voor:

- Skryf 'n brief aan God waarin jy aan Hom verduidelik wat vir jou die heel moeilikste was sedert jou geliefde oorlede is. Skryf dan ook 'n brief aan jouself waarin jy jouself probeer voorstel hoe God jou sou antwoord.

- Jy sou ook 'n brief aan jou oorlede geliefde kon skryf en verduidelik wat vir jou die heel moeilikste was sedert die geliefde oorlede is. Daarna skryf jy weer ' $n$ brief aan jouself waarin jy jouself probeer voorstel hoedat die antwoord sou wees wat jy terugontvang.

\section{Musiek}

Musiek is ' $\mathrm{n}$ uitdrukkingsmedium wat deur talle kinders geniet word. Dit help hulle om te ontspan, te konsentreer, te vier en te rou aangesien dit kragtige emosies ontlok. Daar is verder bevind dat die gebruik van musiek voordelig is ten opsigte van die bevordering van die eiewaarde en selfvertroue, die verbetering van gemoedstemmings, die regulering van emosies en gedrag en die vermindering van angs, vrese en pyn. Musiek is ook ondersteunend tot kinders wat trauma en misbruik ervaar het. Navorsing bevestig dat musiek 'n belangrike bydrae tot kinders se spiritualiteit lewer en gevolglik in 'n beradingsmilieu geïnkorporeer kan word (Boynton \& Vis 2011:150).

\section{Teken}

Tekeninge is dinamies en metafories en het die potensiaal om 'n narratiewe funksie of storievertelling en dramatisering te fasiliteer waardeur kinders openlik betekenis ten opsigte van gebeure of aspekte kan oordra wat vir hulle belangrik is (Boynton \& Vis 2011:149). Binne 'n pastorale konteks waar met jong kinders gewerk word vir wie dit moeilik is om hulle emosies van verlies te verbaliseer, kan hierdie metode baie effektief aangewend word.

\section{Speel en spel}

Die belangrikheid van spel vir kinders terwyl hulle hulle hartseer prosesseer, kan nie genoeg beklemtoon word nie. Spelterapie voorsien ' $n$ nie-bedreigende, veilige, simboliese afstand van die intensiteit van die emosies en indirekte konfrontasie van traumatiese gebeure (Boynton \& Vis 2011:151; vgl. ook die proefskrif van Grobler 2013, vir 'n effektiewe illustrering van die integrasie van spelterapie en die pastoraat in die begeleiding van laerskoolkinders na die dood van 'n ouer).

\section{Storievertelling}

Storievertelling bevat terapeutiese moontlikhede wat kan help om traumatiese gebeure te herstruktureer sodat kinders tot veerkragtigheid en sterker uithouvermoëns bemagtig word. Hierdie verhale kan met behulp van figuurtjies, poppies en toepaslike tekeninge vertel word ten einde nuwe visuele en emosionele denkweë te skep (visual and tactile knowledge pathways; Boynton \& Vis 2011:151).

Geestelike verhale kan as 'n spieël van persoonlike worsteling en oorwinning dien en die deur tot geestelike dialoog open. Leer die kind dat Jesus Christus die helper in smart en vrees is. Hoop word by die treurende gevestig deur verhale voor te lees wat Jesus oor die hemel vertel (Matt 18:10-14) en oor die koninkryk van sy Vader (Matt 13 en Mark 4; Marx 2007:58).

\section{Rituele}

Noah was 9 jaar oud en het probleme ervaar om sy pa se dood te verwerk. Saam met sy berader is toe besluit om 'n fotoplakboek (scrapbook) saam te stel met verhale, foto's en 
stories waarin gebeure en herinnerings rondom sy pa vervat is; om 'n sweetpakbaadjie van sy pa saans by hom in die bed te hou; gebede saans waarin God gevra word om hom te help in sy treurproses; 'n spesiale area in die huis in te rig waar 'n kers op spesiale dae ter herinnering aan sy pa aangesteek word; om die graf op spesiale geleenthede te besoek en ook op sy pa se verjaarsdag ballonne in die lug vry te laat (Boynton \& Vis 2011:148).

\section{Die belangrikheid van openlike kommunikasie tussen ouer en kind}

Die krisis rondom die afsterwe van ' $n$ kind of 'n ouer in 'n gesin bied aan die (oorblywende) ouer die geleentheid om 'n gesprek met die (oorblywende) kind(ers) te begin - wat in 'n sekere sin onbepaald gaan voortduur. Dit is die ouer of versorger se taak om ope kommunikasie te fasiliteer sonder om die kind met 'n oormaat inligting of besluitneming te belas (Stuber \& Mesrkhani 2001:189). Kinders het egter veilige verhoudings nodig om vrymoedig oor onderwerpe soos die lewe, die dood en die hiernamaals te kan praat. In hierdie verband vervul die ouer of die primêre versorger 'n krities-belangrike rol. Die basis van hierdie gesprek bestaan volgens O'Connor (2004:36) uit die volgende vier komponente, naamlik die belangrikheid daarvan om te luister; om met die feite te begin; om aandag aan gevoelens te gee; en om 'n geloofsbasis in die kind se lewe te vestig. Die verskillende komponente sal vervolgens kripties bespreek word.

\section{Die belangrikheid daarvan om te luister}

Om te luister is ' $n$ spesifieke wyse waarop ouers hulle kinders wat deur 'n rouproses gaan en in wie se binneste daar 'n emosionele tornado woed, kan help. O'Conner (2004:57) stel dit soos volg: 'Listening doesn't involve giving advice, offering solutions, seeking details, explaining the unexplainable, or taking charge of the situation. Listening means simply listening.'

Die blote feit dat volwassenes bereid is om aandagtig te luister sonder om te probeer om die kind onmiddellik te verander (fix) is waardevol (vgl. ook Di Ciacco 2008:22). Dit help om 'n vertrouensvlak te vestig waar die kind stelselmatig vanaf kunsmatige en oppervlakkige kwessies na meer belangrike en komplekse aspekte kan beweeg. Perschy (2004) stel dat:

The fact that adults will listen may be more important than actual answers ... Teens then know that they have the capability to explore their beliefs, and can continue to do so until something resonates that is truly authentic for them. (p. 117)

\section{Begin met die feite}

Daar moet in eenvoudige terme aan die kind verduidelik word wat presies gebeur het. Die aantal feite moet in ooreenstemming met die kind se ontwikkelingsvlak wees. Kinders het oor die algemeen ook 'n groter behoefte daaraan om te weet dat die ouer in hulle vrae geïnteresseerd is, eerder as die kwessie of die ouer al die antwoorde op die vrae het.
Leuens, mites en eufemismes (oupa slaap maar net) moet egter vermy word (O'Connor 2004:57).

\section{Gee aandag aan gevoelens}

Elke individu in die gesin het 'n eie, unieke emosionele reaksie op verlies en elke kind moet dus verseker word dat hulle reaksie normaal is. Verder sal kinders oor die algemeen positief reageer en bereid wees om hulle emosies te bespreek indien die ouer(s) bereid is om in die eerste plek hulle eie emosies met die kind te deel (dus ook enige emosies rondom God). O'Connor $(2004: 31,57)$ stel dit dat 'As a parent you go first'.

Gevoelens wat oor die algemeen voorkom en belangrik is, is die volgende:

Woede: Volwassenes kan die kind help om te begryp dat sterk gevoelens van woede dikwels deel van die rouproses is en dat God of hulle geestelike leier nie vir hulle kwaad sal wees omdat hulle hierdie gevoelens ervaar nie (Jerome 2011:204). Wees geduldig wanneer manifestasies van aggressie, regressie, woede en ander emosionele reaksies plaasvind (Marx 2007:58).

Vrese: 'n Sterk geestelike basis kan daartoe bydra dat die vreesrespons tydens trauma en verlies in die kind se liggaam verminder word en dit werk weer die negatiewe effek van stres en angs teë. In hierdie proses kan begeleiers kinders help tot 'n positiewe herbelyning (reframing) van die gebeure wat tot die vestiging van hoop, aanpasbare oorlewing en die vermindering van angsvlakke sal lei (Jerome 2011:198).

Vergifnis: Soms is die begeleiding van kinders vir hierdie aspek nodig. Marshall (2001) vertel van 'n brief wat sy aan haar pa moes skryf 30 jaar nadat hy, reeds voor haar geboorte, uit die huwelik gestap het en haar dus in die steek gelaat het:

Until we reach closure on our grief, it robs us of our today. Strange as it seems, I had carried my anger and grief, very buried, for a lifetime. Once I owned it and expressed it, I could forgive my dad. That's freedom. (p. 164)

Skuldgevoelens: Kinders dink dikwels dat dit hulle skuld is dat ' $n$ geliefde gesterf het. In hierdie opsig het hulle soms leiding nodig ten einde tussen ware en valse skuldgevoelens te kan onderskei (O'Conner 2004:114).

Verwarring: Daar mag soms baie verwarring by jong kinders voorkom aangesien volwassenes aanneem dat hulle nog te jonk is om te verstaan en gevolglik word hulle nie ten opsigte van alle detail en besluite ingelig nie. Hulle neem egter alles waar en dit lei tot verdere verwarring (O'Conner 2004:117).

\section{Vestig 'n geloofsbasis in die kind se lewe}

Daar is oor die algemeen 'n kwalitatiewe verskil waarneembaar ten opsigte van ervarings van rou by diegene met hoop in God, in vergelyking met dié by wie daar geen hoop in God is nie. Deur 'n geloofsbasis by kinders te vestig, bied 
ouers aan hulle ook 'n toekomstige anker vir goeie én slegte tye (O'Connor 2004:46).

\section{Bemoediging}

Wanneer tieners deur die donkerste en mees pynvolle deel van die rouproses beweeg, sou beraders woorde van bemoediging soos die volgende kon aanbied: 'Dit is menslik om jou eie geloofstandpunte te bevraagteken gedurende tye van beproewing.' 'Dit is baie moeilik om sin te maak vanuit sulke aaklige gebeure wat plaasgevind het.' Dit is in orde om vir God kwaad te wees. Goeie vriende kan by tye vir mekaar kwaad wees - 'God kan dit hanteer', aldus Perschy (2004:119).

\section{Daar is 'n element van keuse ten opsigte van die uitkoms van die rouproses}

Dit is belangrik dat kinders ook sal verstaan dat daar 'n keuse-element by die uiteindelike uitkoms van die rouproses betrokke is. Hier kan die voorbeeld gebruik word van die dubbele simbole vir die Chinese woord vir krisis. 'n Simbool word gebruik wat enersyds op gevaar dui, en andersyds een wat op geleentheid dui. Op grond hiervan kan die rouproses in 'n sekere sin as 'n 'gevaarlike geleentheid' beskryf word (Perschy 2004:122). Dit is egter die individu self wat 'n innerlike keuse moet maak om selfs te midde van hartseer die geleentheid aan te gryp om daaruit te leer en uiteindelik emosioneel en geestelik te groei.

\section{Spiritualiteit en posttraumatiese groei}

Spiritualiteit is 'n belangrike faktor ten opsigte van posttraumatiese groei. Deur die nodige bystand tydens die rouproses word die kind se spirituele bronne ook verryk (Boynton \& Vis 2011:138, 142). Kinders wat deur trauma en verlies geraak is, sou op kognitiewe, gedrags- en emosionele terreine groei kon ervaar en in hierdie verband kan spiritualiteit saam met verdere singewende prosesse ' $n$ belangrike rol vervul. Hierteenoor ervaar sommige kinders dat hulle basiese vertroue en gevoelens van voorspelbaarheid deur die trauma en verlies versteur is.

Volwassenes se reaksies op kinders wat rou, is een van die mees belangrike invloede op kinders se reaksies. Wanneer volwassenes byvoorbeeld nie erkenning en bekragtiging (validation) gee aan kinders se gedrags- en emosionele uitdrukkings van rou nie, lei dit tot negatiewe gevoelens soos skuld, woede en magteloosheid. Dit ontneem die kind ook van sekuriteit en ondersteuning en die potensiaal om weer te floreer en sinvol te leef. Sulke kinders mag uiteindelik hulle verlies as onsigbare wonde aan hulle siele beleef, asook 'n onvermoë om te kan voel (dehumanised loss; Boynton \& Vis 2011:141).

Navorsing met kinders toon dat spiritualiteit, as deel van hulle narratiewe, vir hulle belangrik is en dat dit met hulle gesondheid, vreugde en welsyn verband hou. Muselman en Wiggins (2012:229) wys op verskeie studies waarvan die resultate op die belangrikheid van geestelike temas vir kinders en jongmense wys, veral tydens verliese - daarom die belangrikheid dat '... [M]ental health professionals attend to clients' religious and spiritual perspectives when counseling the bereaved' (Muselman \& Wiggins 2012:229). Ongelukkig word laasgenoemde aspek dikwels oor die hoof gesien.

Spirituele praktyke ${ }^{9}$ en geloofstandpunte kan egter tydens die roufase ook posttraumatiese groei en positiewe ervarings tot gevolg hê. As deel hiervan kan geestelike prosesse wat sekere narratiewe en rituele insluit, die verlede oorbrug en kan dit help om by die teenswoordige aan te pas asook 'n roete vir die toekoms te ontdek. Boynton en Vis (2011:145) toon in hierdie verband aan hoedat ' $n$ meta-analise van posttraumatiese groei aangedui het dat 'n herevaluering van self-identiteit en wêreldbeskouing, asook 'n herbesinning rondom spiritualiteit, uiteindelik 'n beduidende rol ten opsigte van positiewe uitkomste vervul het in gevalle van kinders met gekompliseerde rouprosesse (uiteraard met die nodige fasilitering):

Children who experience a loss often emerge from it with advances in empathy, maturity, and a greater appreciaton of the depth of relationships, compared to peers who have not experienced a major loss ... Post-traumatic growth in children is also characterized by personal strengths, enhanced relationships and spiritual change. (Boynton \& Vis 2011:146)

\section{Hoe kan die kind gehelp word om te bid?}

Wanneer kinders intense hartseer beleef as gevolg van verliese, moet hulle aangemoedig word om alle innerlike emosies in gebed met God te deel. Ouers is egter soms geneig om so ' $n$ kind se gebede te wil kritiseer of om hulle 'reg te help'. Marshall (2001) stel dat:

Instead we should open the doorway to God with their honest confusion ... When we interfere with our children's prayers, we block their channel to heaven. We short-circuit His ability to comfort them and become their loving heavenly Father. (p. 98)

Marshall (2001:99) wys ook op die voorbeeld van die sesjarige Elizabeth wie se ouma oorlede is. Die ouma was haar beste vriendin en na die verlies het Elizabeth se gebede skielik verander in 'resentful, ugly talks' met God. Enersyds het haar ouers tydens hierdie fase telkens gevoel om haar te berispe omdat hulle van mening was dat die nodige respek ontbreek het. Andersyds het hulle egter telkens gelei gevoel om nié in te gryp nie. Na verskeie frustrerende weke van trane en verskriklike gebede, het Elizabeth hulle een oggend vroeg, baie opgewonde en met 'n stralende gesig kom wakker maak met die woorde: 'I saw Grandma. She's with Jesus and she's happy. It's white there, and there's music and flowers and Grandma's happy!"'

\footnotetext{
9.Die interpretasie van ' $n$ frase soos hierdie hou weereens verband met die geïntegreerde benadering van Louw (2012:194) wat spesifiek aan ' $n$ Christelike etos gekoppel is, asook 'n praktykgerigte denke, soos aangehaal by paragraaf, 'Fokus sowel as basiese vertrekpunte' van hierdie artikel. Wat spirituele praktyke betref, verwys Boynton en Vis $(2011: 148,151)$ onder andere na aspekte soos gebed en geestelike verhale.
} 
Marshall (2001:99) stel dit soos volg: 'Was it real? A vision? Whatever form it took, it was God loving one of his children.' Hierdie beskrywing is ook in ooreenstemming met Boynton en Vis $(2011: 138,146)$ se benadering:

Although children have less developed cognitive skills and meaning frameworks, they are less constricted by social conventions and are more spiritually open ... [They] may also have spiritual experiences in the midst of a traumatic crisis. (p. 138)

\section{Samevatting en gevolgtrekking}

Die rol wat die kind oor verskeie eeue as die sogenaamde 'forgotten griever' beklee het, kan geensins meer geregverdig word nie en vir kerke om nie oor 'n strategie te beskik om kinders wat in rou is te begelei nie, is nie langer meer aanvaarbaar nie. Indien daar werklik oor die belangrikheid van elkeen binne die geloofsgemeenskap geglo en gepraat word, moet die pastoraat op die kerk as 'n geheel gefokus wees.

Die kerk as die liggaam van Christus, het die onmiskenbare voorreg om 'n positiewe verskil in die lewe van 'n kind wat rou, te maak. Dit kan egter slegs realiseer indien die nodige toerusting met betrekking tot die onderwerp van rou en verlies in die kerk se pastorale kurrikulum geïnkorporeer word. Volwassenes wat by hierdie proses betrokke wil raak, sal oor die nodige kennis en toerusting moet beskik. In hierdie artikel is verskeie aspekte aan die orde gestel wat belangrike komponente van sodanige toerusting sou kon uitmaak.

\section{Erkenning \\ Mededingende belange}

Die outeur verklaar dat hy geen finansiële of persoonlike verbintenis met enige party het wat hom nadelig of voordelig kon beïnvloed het in die skryf van hierdie artikel nie.

\section{Literatuurverwysings}

Ballard, P. \& Pritchard, J., 2006, Practical theology in action, SPCK.

Batten, M. \& Oltjenbruns, K.A., 1999, 'Adolescent sibling bereavement as a catalyst for spiritual growth: A model for understanding', Death Studies 23(6), 529-546. http://dx.doi.org/10.1080/074811899200876

Botha, J.S., 2010, 'Kreatiewe prediking: Kreatiwiteit in diens van die Heilige Gees in die omgewing van die preek', PhD-proefskrif, Departement Praktiese Teologie, Universiteit van Pretoria, Pretoria.

Boynton, H.M. \& Vis, J., 2011, 'Meaning making, spirituality, and creativeexpressive therapies: Pathways to processing grief with children', Counselling and Spirituality 30(2), 137-159.

Bretherton, I., 1992, 'The origins of attachment theory: John Bowlby and Mary Ainsworth', Developmental Psychology 28(5), 759-775. http://dx.doi.org/10.1037/ 0012-1649.28.5.759

Carette, J. \& King, R., 2005, Selling spirituality, Routledge, New York.

Cassidy, J. \& Shaver, P.R. (eds.), 1999, Handbook of attachment: Theory, research, and clinical applications, Guilford Press, New York.

Cochran, J.K., Wood, P.B. \& Arneklev, B.J., 1994, 'Is the religiosity-delinquency relationship spurious? A test of arousal and social control theories Journal of Research in Crime and Delinquency 31(1), 92-123. http://dx.doi. org/10.1177/0022427894031001004

Crehan, G., 2004, 'The surviving sibling: The effects of sibling death in childhood' Psychoanalytic Psychotherapy 18(2), 202-219. http://dx.doi.org/10.1080/14749 730410001700723

Demmer, C. \& Rothschild, N., 2011, 'Bereavement among South African adolescents following a sibling's death from AIDS', African Journal of AIDS Research 10(1), 15-24. http://dx.doi.org/10.2989/16085906.2011.575544
Di Ciacco, J.A., 2008, The colors of grief: Understanding a child's journey through loss from birth to adulthood, Jessica Kingsley Publishers, London.

Dyregrov, A., 2008, Grief in children, Jessica Kingsley Publishers, London.

Erwin, E. (ed.), 2002. The Freud encyclopaedia: Theory, therapy, and culture, Taylor \& Francis, Abingdon.

Forliti, J.E. \& Benson, P.L., 1986, 'Young adolescents: A national study', Religious Education 81(2), 199-224. http://dx.doi.org/10.1080/0034408600810206

Frame, M.W., 2003, Integrating religion and spirituality into counselling: A comprehensive approach, Brooks, Pacific Grove.

Gold, J., 2010, Counselling and spirituality: Integrating spiritual and clinical orientations, Merrill, Upper Saddle River.

Grobler, L., 2013, 'Speel as hulpmiddel in die pastorale versorgingsproses van die getraumatiseerde laerskoolkind as gevolg van die dood van ' $n$ ouer', PhD-proefskrif, Fakulteit Teologie, Noordwes-Universiteit, Potchefstroom.

Hope, R.M. \& Hodge, D.M., 2006, 'Factors affecting children's adjustment to the death of a parent: The social work's professional's viewpoint', Child and Adolescent Socia Work Journal 23(1), 107-126. http://dx.doi.org/10.1007/s10560-006-0045-x

Horsley, H. \& Patterson, T., 2006, 'The effects of a parent guidance intervention on communication among adolescents who have experienced the sudden death of a sibling', The American Journal of Family Therapy 34(2), 119-137. http://dx.doi. org/10.1080/01926180500301519

Houtman, D. \& Aupers, S., 2007, 'The spiritual turn and the decline of tradition: The spread of post-Christian spirituality in 14 western countries, 1981-2000', Journal
for the Scientific Study of Religion 46(3), 305-320. http://dx.doi.org/10.1111/ for the Scientific Study of

James, J.W., Friedman, R. \& Matthews, L.L., 2002, When children grieve, Harper, London.

Jerome, A., 2011, 'Comforting children and families who grieve: Incorporating spiritual support', School Psychology International 32(2), 194-209. http://dx.doi. org/10.1177/0143034311400829

Kaufman, K.R. \& Kaufman, N.D., 2005, 'Childhood mourning: Prospective case analysis of multiple losses', Death Studies 29(3), 237-249. http://dx.doi. org/10.1080/07481180590916362

Kelly, E.W., Jr., 1995, Spirituality and religion in counselling and psychotherapy, American Counselling Association, Alexandria.

Koenig, H.G., 2008, 'Concerns about measuring "spirituality" in research', Journal of Nervous \& Mental Disease 196(5), 349-355. http://dx.doi.org/10.1097/ NMD.0b013e31816ff796

Koenig, H.G., Kvale, J.N. \& Ferrel, C. 1988 'Religion and well-being in later life', Gerontologist 28(1), 18-28. http://dx.doi.org/10.1093/geront/28.1.18

Kübler-Ross, E., 1997, On children and death, Simon \& Schuster, New York.

Lester, A.D., 1995, Pastoral care with children in crises, The Westminster Press, Philadelphia.

Louw, D.A., 1998, Menslike ontwikkeling, HAUM, Kaapstad.

Louw, D.J., 2012, Network of the human soul, Sun Press, Stellenbosch.

Marshall, S., 2001, Take my hand: Guiding your child through grief, Zondervan, Grand Rapids.

Marx, J., 2007, 'Pastorale berading aan kinders met rousmart', MA-verhandeling, Fakulteit Teologie, Noordwes-Universiteit, Potchefstroom.

Mattlin, J.A., Wethington, E. \& Kessler, R.C., 1990, 'Situational determinants of coping and coping effectiveness', Journal of Health and Social Behavior 31(1), 103-122. http://dx.doi.org/10.2307/2137048

Miller, L., 2009, 'Present to possibility: Spiritual awareness and deep teaching', Teachers College Record 111(12), 2705-2712.

Muselman, D.M. \& Wiggins, M.I., 2012, 'Spirituality and loss: Approaches for counseling grieving adolescents', Counseling and Values 57(2), 229-240. http:// dx.doi.org/10.1002/j.2161-007X.2012.00019.x

O'Connor, J., 2004, Children and grief: Helping your child understand death, Revell, Grand Rapids.

Pargament, K.I., Ensign, D.S., Falgout, K., Olsen, H., Reilly, B., Van Haitsma, K. et al. 1990 , 'God help me: Religious coping efforts as predictors of the outcomes to significant negative life events', American Journal of Community Psychology 18(6), 793-824. http://dx.doi.org/10.1007/BF00938065

Perschy, M.K., 2004, Helping teens work through grief, Brunner-Routledge, New York.

Pond, K., 2012, 'A study of childhood grief and the church's response', Christian Educational Journal Series $39(1), 44-64$.

Rankin, J. \& Cochrane R., 2008, The child within: Connecting with children who have experienced grief and loss, Strategies for Hope Trust, Oxford.

Reader, J., 2008, Reconstructing practical theology, Ashgate, Aldershot.

Richards, P.S. \& Bergin, A.E., 2000, 'Toward religious and spiritual competency for mental health professionals', in P.S. Richards \& A.E. Bergin (eds.), Handbook of psychotherapy and religious diversity, pp. 3-26, American Psychological Association, Washington. http://dx.doi.org/10.1037/10347-001

Stifoss-Hanssen, H., 1999, 'Religion and spirituality: What an European ear hears', International Journal for the Psychology of Religion 9(1), 25-33. http://dx.doi. org/10.1207/s15327582ijpr0901_4

Stuber, M.L. \& Mesrkhani, V.H., 2001, 'What do we tell the children? Understanding childhood grief', Western Journal of Medicine 174(3), 187-191. http://dx.doi. org/10.1136/ewjm.174.3.187 
Swinton, J. \& Mowat, H., 2006, Practical theology and qualitative research, SCM, Norwich.

Tanyi, R.A., 2002, 'Towards clarification of the meaning of spirituality', Journal of Advanced Nursing 39(5), 500-509. http://dx.doi.org/10.1046/j.13652648.2002.02315.x

United Nations International Children's Emergency Fund (UNICEF), 2014, 'Orphans and vulnerable children', viewed 05 September 2014, from http://www.unicef. org/southafrica/protection_6631.html
Van der Kolk, B.A. \& Fisler, R., 1995, 'Dissociation and the fragmentary nature of traumatic memories: Overview and exploratory study', Journal of Traumatic Stress 8(4), 505-525. http://dx.doi.org/10.1002/jts.2490080402

Wright, H.N., 2011, The complete guide to crisis and trauma counselling, Regal, Ventura.

Zonnebelt-Smeenge, S.J. \& De Vries, R.C., 2013, 'Childhood and adult grief: Best practices', paper presented at the International Conference of the American Association of Christian Counselors in Nashville, Tennessee, 12th September. 